|IIIIIIIIIIIIIIIIIIIIIIIIIIIIII

学会賞受賞論文

|IIIIIIIIIIIIIIIIIIIIIIIIIIIIIII

（業績賞・研究）

\title{
微生物の生長や分化に関わる生理活性天然物に関する研究
}

\author{
夏目 雅 裕*
}

東京農工大学大学院農学研究院

（2016年6月 12 日受理）

\section{Study on bioactive natural products involved in the growth and morphological differentiation of microorganisms}

\author{
Masahiro NATsume \\ Institute of Agriculture, Tokyo University of Agriculture and Technology, Saiwai-cho, Fuchu, Tokyo 183-8509, Japan
}

Keywords: Streptomyces, aerial mycelium, structure-activity relationship, phytotoxin, germination inhibitor.

\section{はじめに}

生物の生長・分化や生物間の相互作用には，遺伝子やタ ンパク質などの高分子と共に，多種多様な構造と作用を有 する低分子の生理活性物質が重要な役割を果たしている (Fig. 1).このような生命現象を司る生理活性物質を見つけ 出し, その作用機構を明らかにすることは, 生命現象の理解 を深めるだけでなく, 農業生産などの応用面への展開にも大 変重要なことである. 本稿では放線菌にまつわる生理活性物 質に関する我々の研究について紹介する.

\section{1. 放線菌の形態分化と代謝分化の 制御物質に関する研究}

\subsection{Streptomyces albonigerの生産する気菌糸誘導物質 pamamycin}

放線菌の菌糸は, 培地表面や培地中に伸長する基生菌糸 (substrate mycelia）とそれから分化して空気中に伸長する気 菌糸（aerial mycelia）の2 種類がある（Fig. 2). 基生菌糸は

\footnotetext{
* 干 183-8509 東京都府中市幸町 3-5-8

E-mail: natsume@cc.tuat.ac.jp

(C) 日本農薬学会
}

褐色の湿った感じのコロニー表面であるのに対し, 気菌糸は 疎水性の表層構造を有し粉をふいたように見え菌種によって さまざまな色を呈するので, 基生菌糸からの気菌糸の分化は 肉眼でも容易にわかる劇的な形態変化である。 また，気菌糸 を形成しなくなると抗生物質などの代謝産物を生産しなくな ることがあり, 形態分化に伴って, 菌糸の中の代謝系にも変 化が起きていると考えられる，そこで，気菌系を分化誘導す

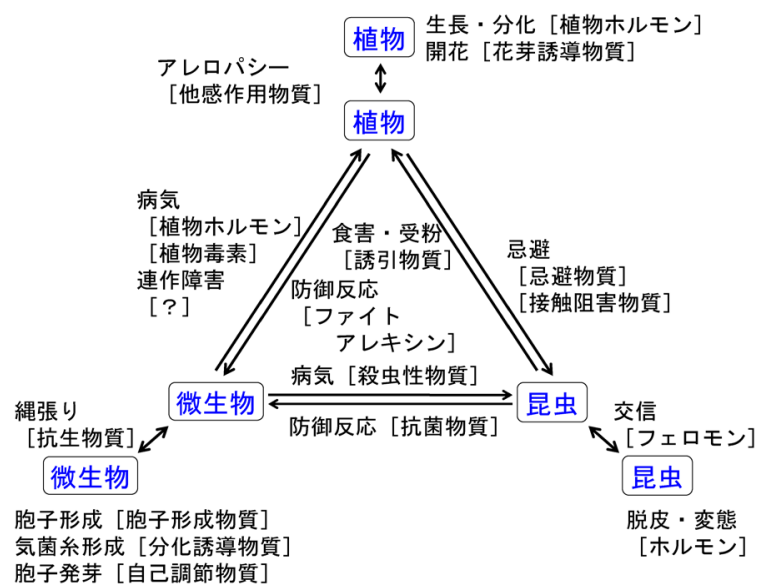

Fig. 1. Physiologically active substances involved in the growth, differentiation and interaction of organisms. 


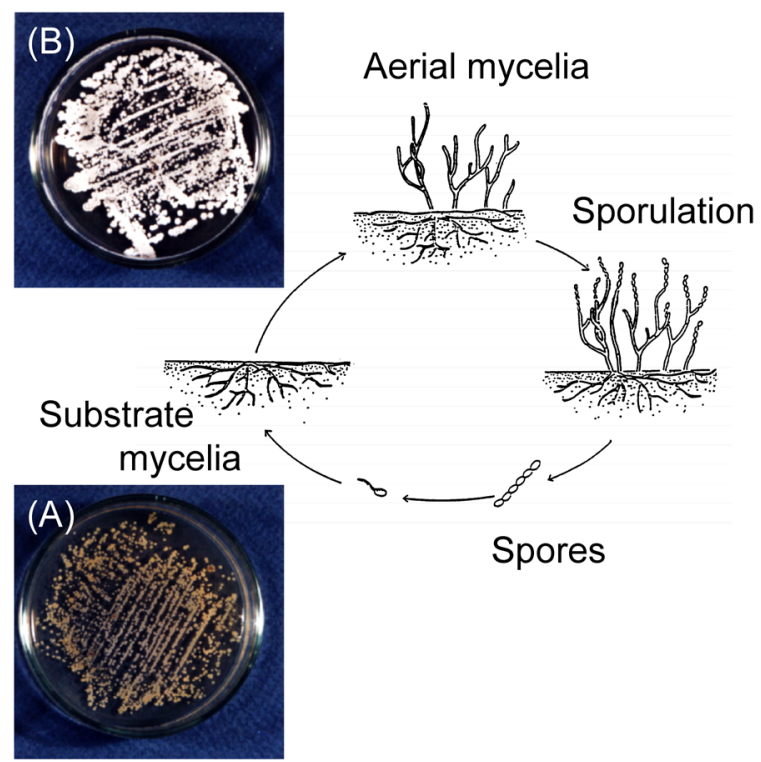

Fig. 2. Life cycle of Streptomyces sp. Growth condition of substrate mycelia (A) and that formed aerial mycelia (B).

る物質が得られれば，物質生産も制御できるのではないかと の考えで研究が開始された。

近藤と丸茂は多数の放線菌をスクリーニングして，S albonigerが気菌糸誘導物質を生産していることを見いだし， 主要な活性物質として pamamycin-607（分子量607）を単離 構造決定した ${ }^{1,2}$ ．その後を受けて，私は以下の研究を行っ た.

\subsection{Pamamycin 同族体・異性体の単離構造決定}

S. albonigerが多くの同族体・異性体を生産すること，ま たそれらの気菌糸誘導活性が異なることは近藤によって示 唆されていた。そこでそれらの精製法を検討した結果，まず ODS-HPLCで精製すると同族体を分離でき，各同族体を次 にアミンを含む順相系溶媒で $\mathrm{NH}_{2}$-HPLCにかけると異性体 を分離できることを見いだした ${ }^{3,4)}$.なぜかは不明だが，逆 の順序では分離がうまくいかなかった。

得られる同族体・異性体が少量のため，構造決定はpamamycin混合物を $\mathrm{LiAlH}_{4}$ 還元して得られるジオールを GC-MS で分析し，di-benzoateに導いて精製・単離して, NMR と MSで構造を決めておいて, 単離した異性体・同族体の一部 （数十 $\mu \mathrm{g} ）$ を $\mathrm{LiAlH}_{4}$ 還元, GC-MS 分析してどのジオールの 組合せかを調べることで行った。その結果，Fig. $3 \mathrm{~A}$ に示す 11 種類の同族体・異性体を得ることができた ${ }^{3,4)}$.

\subsection{Pamamycin の絶対立体配置の決定}

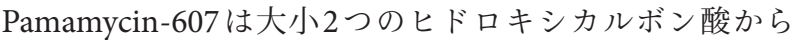
構成されている.小さい方のヒドロキシカルボン酸は殺ダ 二抗生物質として知られる nonactinの構成ヒドロキシカル
(A)

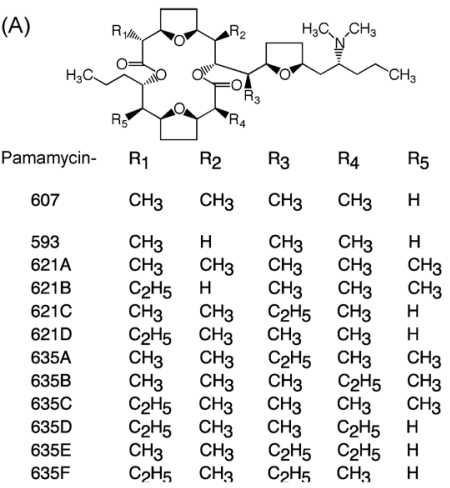

(B)

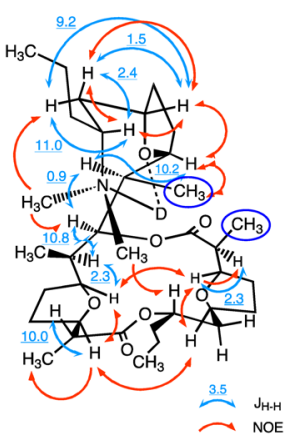

Fig. 3. Structures of isolated pamamycins (A) and conformation of pamamycin-607 (B). $R_{3}$ and $R_{4}$ are indicated by circles.

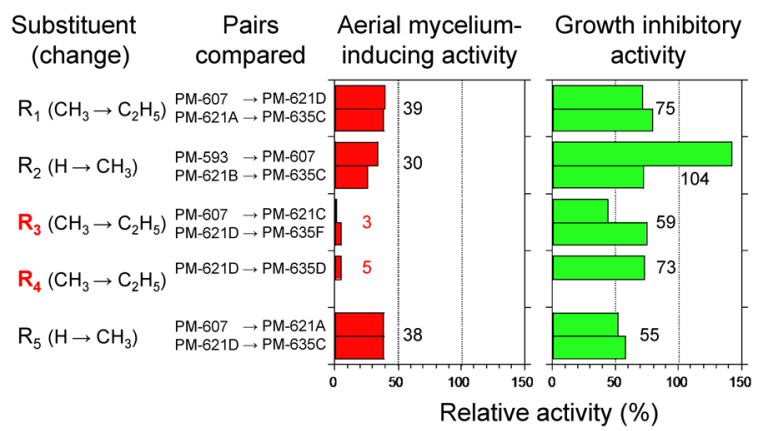

Fig. 4. Effect of alkyl substituemts on biological activities of pamamycins. Numbers in the graphs show mean value of two pairs (except for $\mathrm{R}_{4}$ ).

ボン酸と類似の構造で, 絶対立体配置が決定されていたの で, 両者を同じテトラヒドロフラン誘導体に導き旋光度を比 較することにより, pamamycin-607 の絶対立体配置を決定 した ${ }^{5)}$.また, pamamycin-635Aから得られる小さい方のジ オールの 2 級水酸基の絶対立体配置を改良 Moshier法により 決定し, pamamycin-607 と同じ結論を得た ${ }^{3)}$.

\subsection{Pamamycin の構造活性相関とコンフォメーション}

Pamamycin-607をS. albonigerの気菌糸欠損変異株に与え ると， $0.1 〜 3 \mu \mathrm{g} / \mathrm{disc}$ では気菌糸誘導活性を示すが, $10 \mu \mathrm{g} /$ disc以上では基生菌糸の生育阻害を引き起こす。単離した pamamycin 同族体・異性体の気菌糸誘導活性と生育阻害活 性を調べたところ, 気菌糸誘導活性は同族体・異性体によっ て大きく変化するが, 生育阻害活性はあまり違わないことが わかった。

同族体・異性体の構造を比較すると，5力所のアルキル置 換基 $\mathrm{R}_{1} \sim \mathrm{R}_{5}$ が 1 カ所だけ異なる組合せをみつけることがで きる. 置換基の変化に伴う活性の変化を纒めたのが Fig. 4 で ある。このグラフから, 気菌糸誘導活性は $\mathrm{R}_{3}$ か $\mathrm{R}_{4}$ がメチル 基からエチル基に変化するだけでほとんど失われること, 生 育阻害活性は置換基の位置によらず同程度の低下を示すこと 


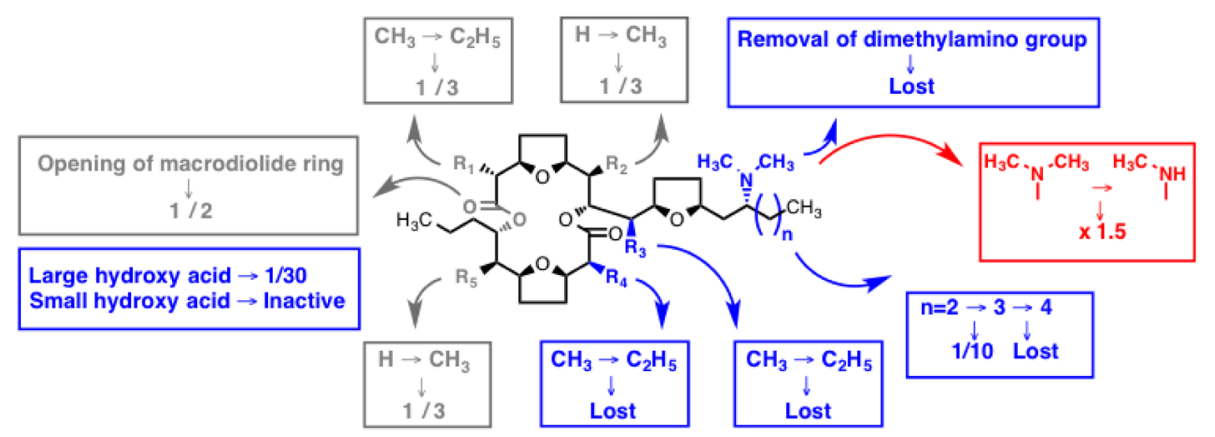

Fig. 5. Structure-activity relationship of pamamycins.

が明らかになり，両者の作用機作は異なることがわかった. また, Pamamycin-607 から化学的に誘導した化合物 ${ }^{6)}$ や . alboniger および別の pamamycin生産菌から分離した側鎖の 異なる同族体など ${ }^{7-9)}$ の活性を調べることにより, pamamycinの気菌糸誘導活性に関する構造活性相関を明らかにした （Fig. 5). 側鎖の窒素原子が活性に必須であること，ジメチ ルアミノ基よりモノメチル体の方が活性が強いこと，側鎖が 長くなると活性が大きく低下することなど，分子の右側部分 が活性に重要であることが明らかになった。

Pamamycinのコンフォメーションを ${ }^{1} \mathrm{H}$ NMRの結合定数 とNOE実験により解析した ${ }^{1,3)}$ (Fig. 3B). その結果, ジメ チルアミノ基のメチル基と小さい方のヒドロキシ酸の水酸基 の付け根のプロトンとの間にNOEが観察され，ジメチルア ミノ基はマクロジオライド環の上側に覆い被さるような形に なっていること，気菌糸誘導活性に大きく影響する置換基 $\mathrm{R}_{3}$ と $\mathrm{R}_{4}$ は分子の外側（Fig. 3Bでは紙面の奥側）に突き出る ような配置になっていることが明らかになった。

\subsection{Pamamycin-607の他の菌の気菌糸形成に及ぼす効 果と作用機構}

S. alboniger と同時期に行われていたS. ambofaciensの気 菌糸誘導物質探索の過程で, $\mathrm{Ca}^{2+}$ が多くの放線菌の気菌糸 形成に重要であることが示された ${ }^{10)}$ 。そこで, Pamamycin-607 と $\mathrm{Ca}^{2+}$ の他種菌株に対する効果を調べたところ，通 常の培養条件では気菌糸を形成せずPamamycin-607 あるい は $\mathrm{Ca}^{2+}$ の投与で気菌糸形成が誘導される菌種と少量の気菌 糸形成が認められるが両者の投与で促進される菌種がテス トした菌種の約7割にのぼり, Pamamycin-607と Ca ${ }^{2+}$ の有 効な菌種がほぼ同じであることが明らかになった ${ }^{11)}$ 。また, pamamycin-607 や $\mathrm{Ca}^{2+}$ が作用を示さなかった菌種には元々 気菌糸を豊富に形成する菌種が多く，これらの菌に $\mathrm{Ca}^{2+}$ の キレート剂であるEGTAを投与すると気菌糸を形成しなく なること, pamamycin-607の気菌糸誘導活性がEGTA で失 われること放) から, pamamycin-607の活性発現に $\mathrm{Ca}^{2+}$ が関 与している可能性が高まった.

そこで, 蛍光色素による放線菌菌体内の遊離 $\mathrm{Ca}^{2+}$ 濃度

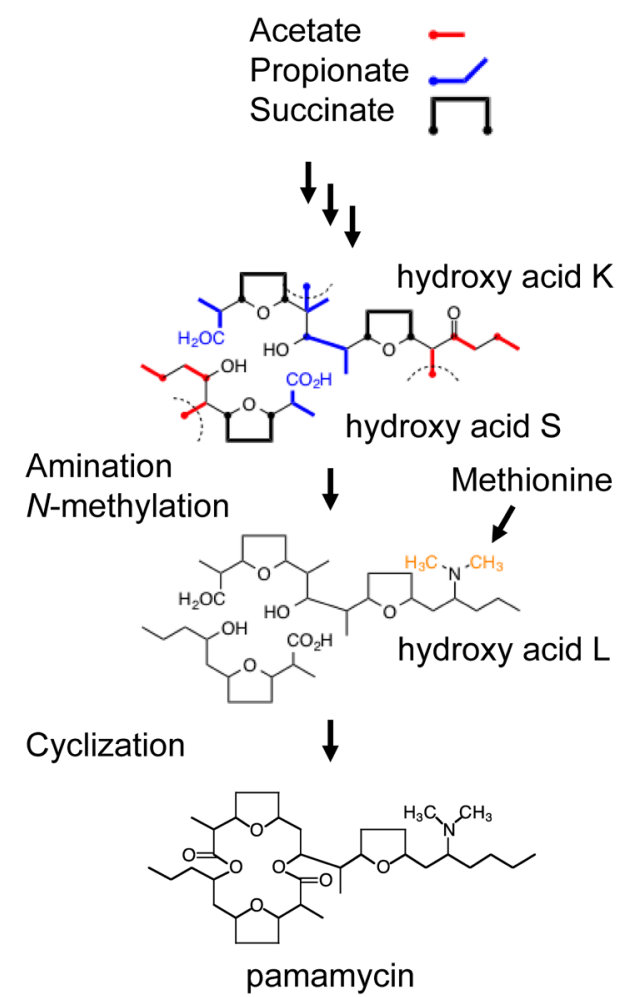

Fig. 6. Biosynthesis of pamamycin-607.

$\left(\left[\mathrm{Ca}^{2+}\right]_{\mathrm{i}}\right)$ を測定したところ, pamamycin-607は $\left[\mathrm{Ca}^{2+}\right]_{\mathrm{i}}$ の 一過的な上昇を引き起こすことを見いだした ${ }^{13)}$. Pamamycin-607には $\mathrm{Ca}^{2+}$ を輸送するイオノフォアの作用はない2）こ とから, pamamycin-607が何らかの $\mathrm{Ca}^{2+}$ 調節系に作用して いると考えられる.

\subsection{Pamamycin-607の他の菌の物質生産に及ぼす効果}

Pamamycin-607によって気菌糸形成が誘導されたり促進 された菌の培養物をコルクボーラーで打ち抜いて寒天ディス クを作成し，B. subtilisに対する抗菌活性を調べたところ，4 菌株で抗菌活性の変化が認められた ${ }^{11)}$ 。この結果は, pamamycin-607 が形態分化と共に代謝分化も誘起することを示し ている。これらの菌の抗生物質を単離同定し, 生産量を定量 


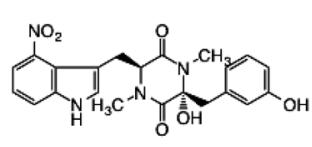

thaxtomin A

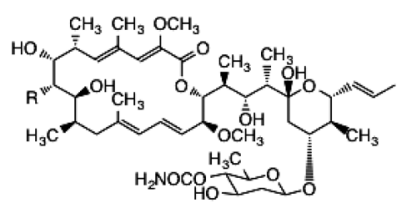

concanamycin $\mathrm{A}\left(\mathrm{R}=\mathrm{C}_{2} \mathrm{H}_{5}\right)$ concanamycin $\mathrm{B}\left(\mathrm{R}=\mathrm{CH}_{3}\right)$

Fig. 7. Phytotoxins produced by phytopathogenic Streptomyces spp.

したところ，150〜270\%の生産増加が認められた ${ }^{14)}$. 以上 の結果から, pamamycinはその添加によりはじめて生産さ れるようになる新規物質の探索や, 生産性の低い有用二次代 謝産物の生産増強に応用できる可能性を示すことができた。

\subsection{Pamamycin の生合成}

標識化合物の取り込み実験 ${ }^{15)}$, 生合成変異株で蓄積する 化合物の分析と, 前駆体と推定される化合物の投与による代 謝実験 ${ }^{16)}$ から, pamamycin はまず大小 2 種類のヒドロキシ カルボン酸が生合成され，大きい方のヒドロキシ酸にジメチ ルアミノ基が導入されて, 最後にマクロジオライド環が形成 される生合成経路 ${ }^{16)}$ (Fig. 6) を提唱することができた.

\section{2. 植物病原放線菌の生産する植物毒素に関する研究}

\section{1. ジャガイモそうか病菌の生産する植物毒素としての} concanamycins の同定

Pamamycinの研究を進めている過程で,「ジャガイモお よびテンサイそうか病菌（Streptomyces spp.）による毒素生 産 I. 炭素源および窒素源の影響について」という酒井ら の論文 ${ }^{17)}$ が目にとまり，ジャガイモそうか病が放線菌によ る病害であることを知った，植物毒素の生産性が培地の炭素 源や窒素源によって変わるなら, 気菌糸形成と植物毒素生産 が関連しているのではないか，そうであれば気菌糸形成の制 御物質でそうか病をコントロールできるのではないか，と考 えた。 また，植物の病害のほとんどは，特定の種の病原菌に よって引き起こされ，特定の病徴を示すが，調べてみると ジャガイモそうか病は変わった病害で, 複数の菌種が関与し ており，病徴も多様であることも興味を引いた。

培地の炭素源と窒素源を変えると気菌糸を形成する組合 せ，形成しない組合せを見つけることができたが，残念な がら気菌糸形成の有無と粗抽出物の植物毒素生産性との 関連は認められなかった。また，この研究を始めて間もな く, Kingらによってジャガイモそうか病菌の生産する植物
毒素として thaxtomins $\mathrm{A}, \mathrm{B}$ が単離構造決定されてしまった (Fig. 7).しかし, 我々の粗抽出物は Dragendorff試薬では 呈色しなかったことから thaxtomin とは異なる植物毒素が生 産されていることが明らかになり，精製を進めた結果，concanamycins A, B を同定した ${ }^{18)}$ (Fig. 7). 2 種類の植物毒素の 存在が明らかになったことで，そうか病が複数の菌種によっ て引き起こされることや多様な病斑が形成されることとの関 係に興味を持った。

\section{2. ジャガイモそうか病菌の分類と concanamycins生産 性との関係}

当時はジャガイモの病原放線菌の分類は確立していな かったが，田代らが胞子鎖の形態やDNA相同性によって 4 種類に分類できることを報告していた ${ }^{19 ）}$ ので，菌株を分譲 していただき，2種類の植物毒素生産性を調べた。その結 果, thaxtominは 4 種類の菌すべてが生産しているのに対し, concanamycinはS. scabiesのみが生産していることを明らか にした ${ }^{20)}$.

\section{3. 病斑型と thaxtomin Aおよび concanamycin生産量 との関係}

代表的な 2 種類のそうか病菌, S. scabies と S. acidiscabies をジャガイモに接種して, 生産される毒素と病徴との関係 を調べた。その結果，S. scabiesはジャガイモに接種した場 合にも2種類の毒素を生産し, 陷没型の病斑を形成させたの に対し，S. acidiscabiesを摂取したジャガイモからはthaxtomin しか検出されず，かさぶた状の隆起型の病斑が形成され $た^{21)}$.

Thaxtomin を発見したグループはそうか病の病斑型の違い は, 生産される thaxtominの量やジャガイモの品種, 病原菌 株の活力, 感染の時期や土壌環境条件などによるのであっ て，植物毒素は thaxtominだけであると主張しているが，こ の実験から concanamycinが同時に生産されるか否かも病斑 型の違いに重要であることが示唆された。

\section{4. ジャガイモそうか病の類似症の病原放線菌が生産す る植物毒素}

ジャガイモそうか病の類似症に russet scabや netted scab と呼ばれる病害がある。そうか病の病斑型に 2 種類の毒素が 関与しているならば，これら類似症には別の植物毒素が関与 していると考えて，これらの菌の生産する植物毒素を探索 した。 その結果, russet scabの病原菌“S. cheloniumii”からは 16員環マクロライド化合物 FD-891 ${ }^{22 ） を ， ま た ス ウ ェ ー テ ゙ ン ~}$ で採集された netted scabの病原菌 S. turgidiscabies \#65から はアントラキノン系化合物 fridamycin $\mathrm{E}^{23,24)}$ を単離同定した (Fig. 7).

残念なのは, 我々が見出した 3 種類の化合物は植物毒素活 
性を示すこととしては初めての報告であったが，いずれもす でに製薬会社等が単離構造決定を報告していた化合物だった ことで, 放線菌については膨大な量の研究がなされているこ とを思い知らされた。

\section{3. 放線菌の自己胞子発芽抑制物質}

\section{1.メロンがんしゅ病菌の自己胞子発芽抑制物質} Hypnosin

糸状菌の胞子に自らの発芽を抑制する物質が含まれている ことは上野と宮川らによるまとまった研究がある ${ }^{25)}$. 放線 菌の場合も，胞子を培地に蒔いてもすべてが同時に発芽す るわけではないことは報告されていた，EnsignらはS. viridochromogenesの発芽中の胞子が他の胞子の発芽を阻害する 物質を培地中に放出することを見いだし，この物質 germicidin（Fig. 8）はその後Petersen らによって単離構造決定され た ${ }^{26)}$. Germicidin $\mathrm{IC}_{50}=5 \mathrm{ng} / \mathrm{mL}$ という極低濃度で胞子発 芽を阻害し，炭素が一つ少ない同族体は活性を示さないと書 かれていた，一方，吉田らはメロンの根に瘤を形成させる病 原放線菌，メロンがんしゅ病菌を発見し，その胞子の発芽率 は $80 \sim 90 \% て ゙ ， 40^{\circ} \mathrm{C} 20$ 分の加熱処理で発芽率が向上するこ とを報告した ${ }^{27)}$.

我々は吉田らから菌株を譲り受け, 自己胞子発芽抑制物 質を探索した，放線菌の胞子は約 $1 \mu \mathrm{m}$ と小さいが，疎水性 の表面構造のためコロニー上にガラスビーズを転がすと，胞 子のみを採集することができる，そこで，3500枚のシャー レ培養物から胞子を集め, 酢酸エチル抽出, シリカゲル・ ODSカラムクロマト，ODS-HPLCで精製することにより発 芽抑制物質 $0.25 \mathrm{mg}$ を単離した ${ }^{28)}$. 胞子のみを集めることで 不純物の少ない粗抽出物を得られたことが比較的簡単な精製 工程で活性物質を単離できた理由であると考えている，構造 決定にはNMRは全く役に立たなかったが，特徴的な UV 吸 収スペクトル（ $\left.\lambda_{\max } 328,318,263 \mathrm{~nm}\right)$ を示したので, 高分 解能質量分析で推定した分子式から可能性のある構造を考 え，UVスペクトルを計算化学により求めて, 実際のスペク トルと比較することにより可能性を絞り込んだ。さらに，誘 導体のマススペクトル解析でカルボキシル基とアセチル基を それぞれ1個ずつ含むことが明らかになったことから，Fig 8 の構造であることを明らかにした ${ }^{29)}$ 。単離した化合物は天 然物としては初めての報告であったので，ギリシャ神話の眠 りの神hypnosに因んでhypnosin と命名した.

Hypnosinは胞子懸濁液に添加してインキュベートすると 発芽による濁度の上昇を抑制するが，胞子の発芽が修了した 36 時間後に添加するとその後の菌糸伸長による濁度の上昇 は阻害しないことから，胞子発芽を特異的に抑制することを 示した $\left(\mathrm{IC}_{50}=0.25 \mu \mathrm{g} / \mathrm{mL}\right)$ 。 また，胞子懸濁液に添加して 3 時間インキュベートした後, 遠心分離により胞子を集め水で 洗浄してからさらに45時間インキュベートすると，発芽し

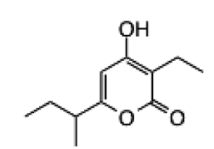

Germicidin S. viridochromogenes

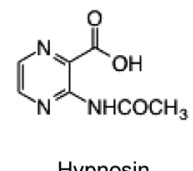

Hypnosin
Streptomyces $\mathrm{sp}$.

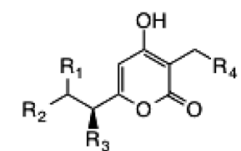

Germicidins A-D (R=H, Me) S. coelicolor A3(2)
Fig. 8. Spore germination self-inhibitors produced by Streptomyces spp.

て無処理の胞子の場合とほぼ同じ濁度を示すことから, 可逆 的に作用していることも示すことができた ${ }^{28)}$.

\subsection{S. coelicolorにおける germicidin の意義と今後の課 題}

その後, 放線菌のポリケタイド生合成を研究しているグ ループがS. coelicolorが germicidin を生産することを発表し たが，彼らの興味はその生合成遺伝子や酵素にあり，生理的 役割については論じられていなかった。 そこでS. coelicolor に打ける germicidinの役割を調べた。その結果, S. coelicolor 4 種類の同族体を生産しており（Fig. 8)，それらはほ ぼ同程度の活性を示し, 発芽抑制活性は $\mathrm{IC}_{50}=20 \sim 100 \mu \mathrm{g} /$ $\mathrm{mL} と S$. viridochromogenesの場合より著しく弱いことが明ら かとなった ${ }^{30)}$. また, germicidin類は胞子発芽と菌系伸長 の両方を阻害した。

同じバイオアッセイで活性を比較していないが，S. viridochromogenes とS. coelicolor で germicidin類の作用が大きく異 なったことから, germicidinはS. viridochromogenesの真の 発芽抑制物質なのか, また, hypnosin と germicidin はStreptomyces属菌の普遍的な発芽抑制物質なのか, 別の菌はまた 別の発芽抑制物質を生産しているのか，ジャガイモそうか病 などの病原放線菌の発芽抑制物質を解明できれば新しい薬剤 になるのではないか，といったことを考えながら研究を継続 している。

\section{おわりに}

大学に入って有機電子論を学び, 細菌の細胞壁であるぺプ チドグリカンの生合成とそれを阻害するペニシリンの作用機 構を反応式で描けることの美しさに魅せられて, 生物現象を 化学の言葉である生理活性物質で説明したいと思い続けなが ら研究を進めてきた。本稿で紹介した研究はすぐに応用に結 びつくものではないかもしれないが，ユニークな視点を示す ことができたのではないかと思っている.

大学の研究室名から農薬の文字が消えはじめて久しいが, 世界人口は増え続けており, 食糧供給・作物保護の必要性は ますます高まっている，大学人としてこの課題にどのように 取り組むかは大きく難しい問題で, 農薬化学から名称变更し た研究室の多様さがそのことを表しているように思う。私と しては, 新しい生理活性物質を見つけ, 新しい作用を明らか 
にし，生物の仕組みや生物間の相互作用の理解を深めること で，少しでも貢献できると信じて，研究を続けていきたい。

\section{謝 辞}

本研究は名古屋大学大学院農学研究科農薬化学研究室と東 京農工大学大学院農学研究科生物制御化学研究室において, 多くの学生とともに行ってきたもので, 本学会賞の栄誉を彼 らと分かち合いたいと思います。名古屋大学名誉教授, 丸茂 晋吾先生には卒業研究から助手時代まで, 公私にわたりご指 導ご鞭撻を賜りました。 心より感謝申し上げます。また，東 京農工大学名誉教授, 安部浩先生, 安藤哲先生には常に温か く励まして頂きました。厚く御礼申し上げます。

植物病原放線菌の生産する毒素の研究では佐賀県農業試験 場の田代暢哉博士に，自己胞子発芽抑制物質に関する研究で は東海大学農学部の吉田政博教授に大変お世話になりまし た.さらに，個々にお名前は挙げられませんが多くの方々に ご協力，ご指導を頂きました。ありがとうございました。

\section{引 用 文 献}

1) S. Kondo, K. Yasui, M. Katayama, S. Marumo, T. Kondo and H. Hattori: Tetrahedron Lett. 28, 5861-5864 (1987).

2) S. Kondo, K. Yasui, M. Natsume, M. Katayama and S. Marumo: J. Antibiot. 41, 1196-1204 (1988).

3) M. Natsume, K. Yasui, S. Kondo and S. Marumo: Tetrahedron Lett. 32, 3087-3090 (1991)

4) M. Natsume, J. Tazawa, K. Yagi, H. Abe, S. Kondo and S. Marumo: J. Antibiot. 48, 1159-1164 (1995).

5) M. Natsume, S. Kondo and S. Marumo: J. Chem. Soc. Chem. Com mun., 1911-1913 (1989).

6) M. Natsume, A. Honda, Y. Oshima, H. Abe, S. Kondo, F. Tanaka and S. Marumo: Biosci. Biotechnol. Biochem. 59, 1766-1768 (1995).

7) I. Kozone, H. Abe and M. Natsume: J. Antibiot. 52, 329-331 (1999).

8) I. Kozone, H. Abe and M. Natsume: J. Pestic. Sci. 26, 149-153 (2001)

9) I. Kozone, M. Hashimoto, U. Gräfe, H. Kawaide, H. Abe and M. Natsume: J. Antibiot. 61, 98-102 (2008).

10) M. Natsume, K. Yasui and S. Marumo: J. Antibiot. 42, 440-447 (1989).

11) M. Hashimoto, T. Kondo, I. Kozone, H. Kawaide, H. Abe and M. Natsume: Biosci. Biotechnol. Biochem. 67, 803-808 (2003).
12) M. Natsume and S. Marumo: J. Antibiot. 45, 1026-1028 (1992).

13) M. Natsume, J. Tazawa, H. Abe, Y. Kudo, S. Kondo and S. Marumo: Biosci. Biotechnol. Biochem. 59, 152-154 (1995).

14) M. Hashimoto, H. Katsura, R. Kato, H. Kawaide and M. Natsume: Biosci. Biotechnol. Biochem. 75, 1722-1726 (2011).

15) M. Hashimoto, I. Kozone, H. Kawaide, H. Abe and M. Natsume: J. Antibiot. 58, 722-730 (2005).

16) M. Hashimoto, H. Komatsu, I. Kozone, H. Kawaide, H. Abe and M. Natsume: Biosci. Biotechnol. Biochem. 69, 315-320 (2005).

17) R. Sakai, H. Kawamura, Y. Mino, E. S. Reza and A. Tanii: Ann. Phytopathol. Soc. Jpn. 50, 646-648 (1984).

18) M. Natsume, R. Ryu and H. Abe: Ann. Phytopathol. Soc. Jpn. 62, 411-413 (1996).

19) N. Tashiro, K. Miyashita and T. Suzui: Ann. Phytopathol. Soc. Jpn. 56, 73-82 (1990).

20) M. Natsume, A. Yamada, N. Tashiro and H. Abe: Ann. Phytopathol. Soc. Jpn. 64, 202-204 (1998).

21）夏目雅裕：馬鈴しょそうか病に関する国際シンポジウム, 講演・ ポスターセッション要旨集, pp. 42-55, 2004.

22) M. Natsume, M. Komiya, F. Koyanagi, N. Tashiro, H. Kawaide and H. Abe: J. Gen. Plant Pathol. 71, 364-369 (2005).

23) 長潟麻穂, M. Aittamaa, J. P. T. Valkonen, 川出 洋, 夏目雅裕 : 日本農薬学会第 34 回大会講演要旨集, p. 104, 2009.

24）岡庭奈保子, 長潟麻穂, J. P. T. Valkonen, 川出 洋, 夏目雅裕： 日本農薬学会第 39 回大会講演要旨集, p. 61, 2014.

25）上野民夫，宮川 恒：植物病害の化学，市原耿民，上野民夫編， 学会出版センター, pp. 203-214, 1997.

26) F. Petersen, H. Zähner, J. W. Metzger, S. Freund and R. P. Hummel: J. Antibiot. 46, 1126-1138 (1993).

27）吉田政博, 西山隆行, 山口武夫, 小林研三：日植病報 60, 711716 (1994)

28) Y. Aoki, M. Yoshida, H. Kawaide, H. Abe and M. Natsume: Biosci. Biotechnol. Biochem. 71, 986-992 (2007).

29) Y. Aokim, M. Yoshida, H. Kawaide and M. Natsume: J. Agric. Food Chem. 55, 10622-10627 (2007).

30) Y. Aoki, D. Matsumoto, H. Kawaide, H. Abe and M. Natsume: J. Antibiot. 64, 607-611 (2011).
略 歴
夏目雅裕（なつめ まさひろ）
生年月日：1956年10月 12 日
最終学歴：名古屋大学大学院農学研究科博士課程（単位取得 退学), 博士 (農学) (名古屋大学)
研究テーマ：微生物の形態分化と代謝分化や微生物と植物の 相互作用の化学的解明 